A verbatim copy of the Medical Registration Bill of Mr. Brady now before the House of Commons, will be found below. The honourable member has requested us to state that the two last clauses are not to be considered as finally settled.

\section{MEDICAL REGISTRATION BILL.}

\section{A BILL}

\section{THE REGISTRATION OF QUALIFIED PRACTT- TIONERS, AND FOR AMENDING THE LAW RELATING TO THE PRACTICE OF MEDICTNE, IN GREAT BRITAIN AND IRELAND.}

[Note. - The Words and Clauses printed in Italics are proposed to be inser ted in Committee.]

WHEREAs it is expedient to amend the laws relating to the practice of medicine and surgery in Great Britain and Ireland, and to provide means whereby the duly qualified practitioners in the various branches of the medical profession in Great Britain and Ireland may be readily known and distinguighed: be it therefore enacted by the Queer's most excellent majesty by and with the advice and consent of the lords spiritual and temporal, and corrmons, in this present parliament assembled, and by the authority of the same, as follows:-

I. One of her majesty's principal secretaries of state shall, within after the passing of this Act, nominate three fit and proper persons, being at the time of such appointment members of the medical profession, and duly qualitied to be registered under the provisions of this Act, to be registrars for carrying this Act into execution, one such registrar to be called "The Medical Registrar for England," another "The Medical Registrar for Ireland," and one "The Medical Registrar for Scotland;" and the said secretary of state shall also from time to time appoint such clerks and other officers as he shall deem necessary for the assistance of the said registrars in carrying into execution the provisions of this Act; and that the said secretary of state may, at his discretion remove any registrar or other person so appointed as aforesaid; and that upon the death or resignation of any such registrar, clerks, or other officer as aforesaid, or other vacancy in either of the offices so filled, the said secretary of state shall appoint other proper persons to be such registrars, clerks, and officers respectively, and there shall be paid to the said registrars, clerks, and officers respectively, out of any money to be received by the said registrars by virtue of this Act, such salaries as shall be from time to time fixed and allowed by the lord high treasurer or the commissioners of her majesty's treasury, who may also allow such reasonable travelling expenses as may be incurred by any registrar, dierk, or other officer in the performance of his duties under this Act, and such other reasonable expenses for putting and carrying this Act into execution as the said lord high treasurer or the commissioners for the time being of her majesty"s treasury shall think fit.

II. The duties of the several registrars shall be to register, within after their appointment, and from time to time afterwards, in books to be kept for that purpose, the christian and surname and place of residence, together with $a$ description of the professional and legal qualifications or qualification, with the date or dates thereof, of every physician, surgeon, or apothecary, who shall apply to be registered, and of every person who shall apply to be registered, who was actually practising as an apothecary in England and Wales prior to the first clay of August, one thousand eight hundred and fifteen, and who shall sign a declaration according to the form of schedule (A.) to this Act annexed, and also of every surgeon and assistant-surgeon in the army and navy, and in the service of the Hon. East India Company, who shall apply to be registered as aforesaid.

III. Every person legally qualified to practise medicine or surgery, either as a physician, surgeon, or apothecary, shall between and of the same month inclusive in the rear one thousand eight hundred and fifty-five, and in every succeeding year, deliver or cause to be delivered at the office of the medical registrar of that part of the United Kingdom where the said person is legally entitled to practise, his legree, diploma, or licence, or an attested declaration made before one of her majesty's justices of the peace, in which his qualifications or qualification, with the date or dates thereof, shall be duly set forth, or such other proof as shall be satisfactory to the said registrar of his having obtained a degree, diplonm, or licence to practise as a physician, surgeon, or apothecary, with the date or dates thereof.

IV. Every person applying to hare his name registered shall pay to the registrar the sum of five shillings, and on his being registered, such registration shall bear date on the day on which the same shall be made, and if made in the year One thousand eight hundred and fifty-four, shall continue in force from the date of such registration until the Thirty-first of December, One thousand eight hundrcd and fifty-fire, and no longer; and the said registrars shall, at any time in the year last mentioned, or at any time in every subsequent year, upon the application of any person who shall be then registered, issue a certificate according to Schedule (B.) to this Act annexed to such person, subject to the payment of a sum not exceeding two shillings and sixpence, which said certificate shall be duly sealed or stamped with the seal of the registrar's office, to be provided as hereinafter mentioned, and shall be evidence in all courts and before all justices of the peace and others that the person thercin specified has been duly registered according to the provisions of this Act.

V. Each of the siid registrars shall cause to be made a seal for their respective offices, and the said registrars shall cause to be sealed or stamped therewith all certificates or other documents issued by them under the provisions of this Act; and all sucil certificates or other documents purporting to be sealed or stamped with the seal of the said registrars' offices, or either of them, shall be received as evidence of the registration of the person named in such certificate, without any further proof; and no certificate purporting to be issued from the offices of the said registrars, or either of them, shall be of any force or effect which is not sealed or stamped as aforesaid.

VI. On or before the Thirty-first Day of January in every year, each of the said registrars shall cause to be printed and published a correct registrar according to the form in Schedule (C.) to this Act, annexed of the names and places of residence, arranged alphabetically, of all persons duly registered during the year then last past, according to the provisions of this Act, together with a description of their legal qualification or qualifications, with the date and dates thereof, and such registers shall be respectively called "The Medical Register" for England," "The Medical Register for Ireland," and "The Medical Register for Scotland."

VII. All persons whose names, qualifications, and addresses are in any one or all of the said urinted registers for the time being so published as aforcsaid, shall be taken and deemed in all courts and before all justices of the peace and others to be duly registered according to the provisions of this Act, and copies of such medical registers shall be furnished by the registrars to every person who shall apply for the same, uyon raxment of a sum not exceeling one shilling for each copy.

VIII. Any person who shall wilfully cause or procure, or attempt to procure by false declaration or resresentation, the insertion of his name in any or all of the aforesaid registers as a legally qualified practitioner, if the offence be committed in England or Iroland, shall on conviction be adjudged guilty of a misdemeanour, and if in Scotland of a crime and offence, and thereupon it shall be lawful for the court before whom such offender or offenders slall be tried and convicted, to sentence such offender or offenders to be imprisoned, with or without hard labour, for any period of time not exceeding tuclet calendar months.

IX. Any person who shall wilfully destroy or injure, or canse or procure to be destroyed or injured, any such register, cer. tificate, or other document to be made under the provisions of this Act, or shall make or counterfeit any such register, certificate, or other document as aforesaid, or shall force or counterfeit the seal or seals of any of the said registrars offices, shall be deemed and taken to be guilty of felony.

$\mathrm{X}$. Any registrar to bo appointed under this Act who shall wilfully make or cause to be made any false entry in any register, certificate, or record as aforesaid, shall, if the offence be committed in England or Treland, be deemed guilty of a misdemeanour, and if in Scotlind of a crime and offence, and shall on conviction thereof be sentenced to be imprisoned for any term not exceeding six calendar months.

XI. Any person who shall after the passing of this Act practise or act as a plyysician, surgeon, or apothecary, for gain or reward, or who shall contract or agree to act as aforesaid for gain or reward, or use the title of physician, surgeon, or 
apothecary, without being duly registered under the provisions of this Act, shall, on conviction before any magistrate having jurisdiction in the county, city, or place where the offence was committed, be liable to be tined for every such offence in a sum not exceeding [tacenty] pounds nor less than [ five] pounds, or in default of payment, to be imprisoned in any of her Majesty's gaols for a period of not more than [six] months nor less than [one] inonth.

XII. If any person legally entitled to be registered according to the prorisions of this Act, and whose name and place of residence, and a correct description of whose qualification or qualifications, with the date or dates thereof, do not appear in such register as aforesaid, shall at any time apply to any of the registrars as aforesaid to be registered according to the provisions of this Act, and shall prove to the satisfaction of such registrar, either that he is a person whose name, through his own neglect or mistake, has becn omitted from the medical register then current, or that he intends commencing or resuming practice, every such applicant shall be entitled to be registered by the registrar appointed for that yart of the United Kingdom in which he resides, upon payment of [tuenty] shillings and sending his name and then place of residence, together with a description of his qualification or qualifications, with the date or dates thereof, which registration shall continue in force until

XIII. After the completion of the registers to be provided maler this Act, no person shall be entitled to recover in any court of law or equity any charge for any medical or surgical alvice, attention, or for the performance of any operation, or for any medicine presented, administered, or supplied by him, unless lie shall prore upon the trial that he is duly registered as aforesaicl, or that he was legally practising in the capacity in which he claims such charge at the time when the delot was contracted.

XIV. Nothing in this Act contained shall extend or be construed to extend to the profession or business of any dentist or cupper who was engaged in such profession or business on or before the First Day of March, One thousand eight hundied and fifty-four, bat every such dentist or cupper shall conduct such profession or business in as free and ample a manner as though this Act had not been passed.

$X V$. The words legally qualified medical and surgical practitioners shall be taken to mean all members of the medical profession who have or hereafter shall have received degree, dijloma, or licence from any one or all of the medical corporate bodies at present legally entitled to grant a licence to practise medicine or surgery, or any medical corporate body that may hereafter be so authorized by law to grant such degree, diploma, or licence, as aforesaid.

XVI. And whereas there are many physicians, graduates of British and Irish Universities, now practising in England, who have not a lergal qualification to practise in England and Wales: be it enacted, that they shall be allowed to contimue to practise as pliysicians for one year from the date of the passing of this Act, in order to afford them an opportunity to obtain a legal qualification, and until such qualification be ubtained, they are hereby authorized to be provisionally registered according to the provisions of this Act for the said yeriod of one ycar, and no longer.

XVII. Provided always, That nothing herein contained shall apply to plyssicians, graduates as aforesaid, who have heen in practice as physicians for a period of years.

\section{SCHEdULe (A.)}

Declaration required of a person who claims to be registered as a medical prictitioner, upon the ground that he was in practice as a medical practitioner before the First Day of August, One thousand eight hundred and fifteen:-

To the Registrar for England.

I, [John Thomas], residing at [6, Duke-street, Exeter], in the county of [Devon], hereby declare, That I was practising as a medical practitioner, at [16, George-street, Hastings], in the county of [Sussex], before the First Day of August, One thousand eight hundred and fifteen.

(Signed)

Dated this [6th] day of [Jamuary], 185

$$
\text { [Joms Thomas.] }
$$

\section{SCHEDLLE (B.)}

The Medical Register for England. MEDICAL REGISTRATION CERTIFICATE.

By virtue of the Powers invested in me by an Act of Parliament passed in the
Queen Victoria, intituled "An Act for the Registration of qualified Medical Practitioners, and for amending the Law relating to the Practice of Medicine and Surgery, in Great Britain and Ireland," I hereby certify, that John Thomas, residing at No. 5, Temple-place, Liverpool, in the county of Lancashire, has been duly registered according to the provisions of the said Act as a person who is legally qualified to practise as a [physician, surgeon, or apothecary] in any part of [England and Wales], and that he is entitled to exercise all the powers and privileges conferred by the said Act.

This certificate to remain in force until the thirty-first day of December, One thousand eight hundred and fifty five. (Signed) HENRY ARMSTRONG,

Dated, London, 10țh June, 1854 Medical Registrar for [England].

SCHEDULE (C).

The Medical Register for [England], consisting of the names and places of residence, [arranged] alphabetically, with descriptions of the qualifications, and the dates thereof, of all persons legally qualified to practise medicine and surgery in [Fngland] in the year 185 .

The Names of registered Medical Practitioners arranged alphabetically.

\begin{tabular}{|c|c|c|}
\hline Names. & Qualifications. & Places of Residence \\
\hline Abbot, John ... & $\begin{array}{l}\text { Fellow of the Royal College } \\
\text { of Physicians of London, } \\
\text { obtained 10th Aug. } 1826 .\end{array}$ & \\
\hline Abbey, James... & $\begin{array}{l}\text { Fellow of the Royal College } \\
\text { of Surgeons, England, ob- } \\
\text { tained June, } 1840 \text {. }\end{array}$ & \\
\hline Akenside, Thos. & $\begin{array}{l}\text { Licentiate of the Society of } \\
\text { Apothecaries, London, ob- } \\
\text { tained June, } 1830 \text {. }\end{array}$ & \\
\hline
\end{tabular}

Places.

Bath... ... ... Adams, John; 6, Henrietta-street.

Chester $\quad \ldots . \quad \ldots$ Clerk, Andrew; 24, Charles-street.

London ... ... $\quad$ Brady, Chas.; 194, Blackfriars-road.

\section{SAledical Societies.}

\section{MFDICAL SOCTETY OF LONDON.}

SATURDay, Feb. 11, 1854.-Dr. Tyler Smith, V.P., IN THE CHATR.

CASE OF LACERATION OF THE PERINACUM.

Mr. I. B. Brown mentioned a case of ruptured perinæun, on which he had operated two or three years since with success. The patient had suffered for years from this distressing malady. The injury involved half the sphincter and half the vaginal septum. This lady had become pregnant, and was taken in labour a few days since, and was delivered safely of a very large child. The labour was somewhat protracted, and it was thought at one time that it might be desirable to divide the perinæum laterally, to allow the head to pass. This, howerer, was not resorted to, and the child was born with only a slight laceration of the new perinæum to the extent of an inch. The child's head was fourteen inches and a half in circumference; the shoulders seventeen inches and a half. The patient had made a good recovery, the perinæum was perfect, and the action of the sphincter complete. The cases of ruptured perinæum on which he had operated successfully now exceeded twenty, and of these five of the subjects had been delivered safely of children since the operative procedure.

Dr. Burke Ryan wished to know the experience of $\mathrm{Mr}$. Brown upon two points brought forward by Dr. Ryan during the discussion of Mr. Brown's paper some time ago-namely, the difference it might make in the operation for ruptured perinxum of long standing, if the patient were or were not beyond the age of childbearing. In the former case, in order more perfectly to support the uterus, the perinæum might be fully restored; but in the latter case it might be a question 